\title{
High-latitude Late Jurassic nannofossils and their implication for climate and palaeogeography
}

\author{
Mikhail A. Rogov' ${ }^{1,2} \&$ Maria A. Ustinova ${ }^{1}$ \\ ${ }^{1}$ Geological institute of RAS, Pyzhevski lane 7, 119017 Moscow, Russia. \\ ${ }^{2}$ Saint Petersburg State University, Universitetskaya nab. 7/9, Saint Petersburg 199034, Russia. \\ E-mail corresponding author (Mikhail A. Rogov): russianjurassic@gmail.com
}

\begin{abstract}
Jurassic high-latitude records of calcareous nannoplankton are insufficiently known, as this group was generally restricted to low and middle latitudes during the early stages of its evolution. Here, we report the first finding of Late Jurassic (Kimmeridgian) calcareous nannoplankton from a near-polar site, the Nordvik section, north of Central Siberia, at $\sim 78^{\circ} \mathrm{N}$ palaeolatitude. Calcareous nannoplankton here are represented mainly by the dissolution-resistant cosmopolitan genus Watznaueria. Its occurrence is possibly caused by the coupled influence of climate warming during the Late Jurassic and peculiarities of warm currents. This suggestion is strongly supported by sets of independent evidence, including the presence of numerous Subboreal aulacostephanid ammonites in the Kimmeridgian of the Yenisei-Khatanga Strait, as well as thermophilic pollen in palynological samples, and by oxygen stable-isotope values derived from belemnite rostra which agree with general circulation models. Strong palaeotemperature control on aulacostephanid ammonite distribution is suggested for the Kimmeridgian of the Yenisei-Khatanga Strait.
\end{abstract}

Keywords: calcareous nannoplankton; palaeogeography; Kimmeridgian; Jurassic; palaeogeography; palaeoclimate; ammonites

Received 11. November 2017 / Accepted 18. January 2018 / Published online 26. February 2018

\section{Introduction}

Jurassic calcareous nannofossil records are mainly restricted to low- or mid-latitude sites and are extremely rare at high latitudes. Diverse nannofossil assemblages (up to 10-15 genera) are known from the Upper Jurassic of the Middle Volga and Moscow areas (Ruffell et al., 2002; Ustinova, 2009; Ustinova, 2017a) while relatively sparse and low-diversity Kimmeridgian and Volgian nannofossil assemblages are known from the northern parts of the Russian Platform (Gavrilov et al., 2008; Ustinova, 2017b) as well as from the Barents Sea shelf (Smelror et al., 1998; Mutterlose et al., 2003). At least six nannofossil species were reported by Zanin et al. (2012) from the J/K transition beds of Western Siberia. Previously known high-latitude occurrences of Upper Jurassic and Lower Cretaceous nannofossils lie near $50-55^{\circ} \mathrm{N}$ palaeolatitude (Mutterlose \& Kessels, 2000;
Mutterlose et al., 2003), with the northernmost record of the Watznaueria britannica found in the Kimmeridgian of borehole 7430/10-U-01 (Barents Sea shelf, 61$62^{\circ} \mathrm{N}$ palaeolatitude, see Smelror et al., 1998), nearly corresponding to the southernmost subpolar Jurassic occurrence of nannofossils $\left(60^{\circ} \mathrm{N}\right.$ palaeolatitude) at the Falkland Plateau (Bown, 1996). High-latitude nannofossil assemblages generally have a low diversity and are characterised by an abundance of Watznaueria barnesae and Crucibiscutum salebrosum. The latter species shows a bipolar distribution during the Valanginian-Hauterivian (Mutterlose et al., 2005). This paper provides the first evidence of nannofossils derived from the Kimmeridgian of an extreme Arctic area, the Nordvik section of the Laptev Sea coast (Fig. 1), which was located at a very high latitude during the Late Jurassic. 


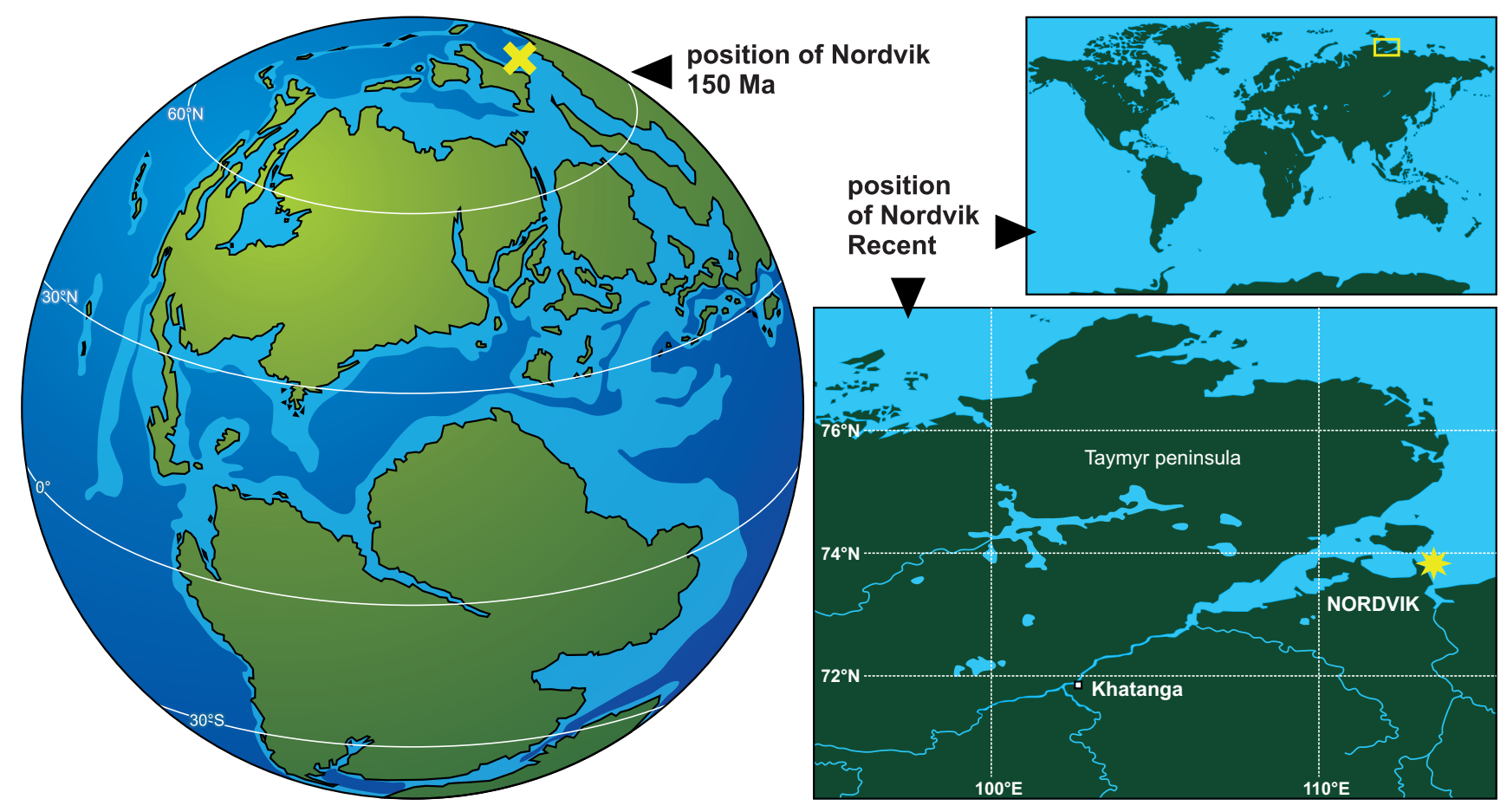

Figure 1. Location map showing the position of the Nordvik section.

\section{Material and geological setting}

Nannofossil samples for this study were collected by one of the authors (MR) during fieldwork in 2003, simultaneously with ammonites and belemnites providing strong biostratigraphical control (Zakharov et al., 2014). There are 37 samples in total, collected from the Oxfordian to Ryazanian, with an average sample step of $1 \mathrm{~m}$. Volgian and Oxfordian samples lack nannofossils, while the Ryazanian ones are still under investigation.

The Nordvik section, located on the Urdyuk-Khaya Cape along the Laptev Sea coast (Fig. 1), is well known for its continuous Jurassic-Cretaceous transition record and considered as a very important reference section for the North Siberian Oxfordian-Valanginian (Nikitenko et al., 2013; Zakharov et al., 2014). This section is dominated mainly by mudstones and black shales with numerous phosphorite and carbonate concretions, deposited in relatively deep-marine conditions ( $200 \mathrm{~m}$ depths). Succession also include thin bands enriched in glauconite (in the uppermost Middle Volgian) or represented by silt (Middle Oxfordian and Oxfordian-Kimmeridgian boundary beds). Since this section was discovered, it has been intensively studied by geoscientists. Detailed investigations of ammonite-, belemnite- and bivalve-based biostratigraphy (Zakharov et al., 1983, 2014; Zakharov \& Rogov, 2008; Rogov \& Wierzbowski, 2009; Dzyuba, 2012; Nikitenko et al., 2013, 2015), dinocyst and foraminiferal records (Nikitenko et al., 2008, 2015), supported by palaeomagnetic data
(Houša et al., 2007; Bragin et al., 2013; Schnabl et al., 2015) and geochemical (stable isotopes) characteristics (Žák et al., 2011; Dzyuba et al., 2013) place this section among the most well-studied Upper Jurassic Boreal sites. The palaeolatitude of the Nordvik site for the Volgian has been determined as $74^{\circ} \mathrm{N}$ (Žák et al., 2011), which is similar to Kimmeridgian palaeolatitudes $\left(78,4^{\circ} \mathrm{N}\right)$ calculated using the paleolatitude.org online facility (van Hinsbergen et al., 2015).

The Kimmeridgian ammonite biostratigraphy of this section (Rogov \& Wierzbowski, 2009; Wierzbowski \& Rogov, 2013; Nikitenko et al., 2013) includes a nearly full succession of Boreal ammonite zones, based on cardioceratid records as previously recognised in the Barents Sea shelf (Wierzbowski \& Smelror, 1993) and other Arctic sites. Among the other ammonites, only the endemic Boreal oppeliid Suboxydiscites is known from the Kimmeridgian of this section, while Subboreal Aulacostephanids are entirely absent here.

\section{Kimmeridgian nannofossils of the Nordvik section}

Among the 37 samples for nannofossil analysis (Fig. 2) the Volgian and Oxfordian ones lack nannofossils, while the Kimmeridgian samples show low-diversity and sparse nannofossil assemblages. All studied nannofossils are poorly preserved and typically have a corroded 
A

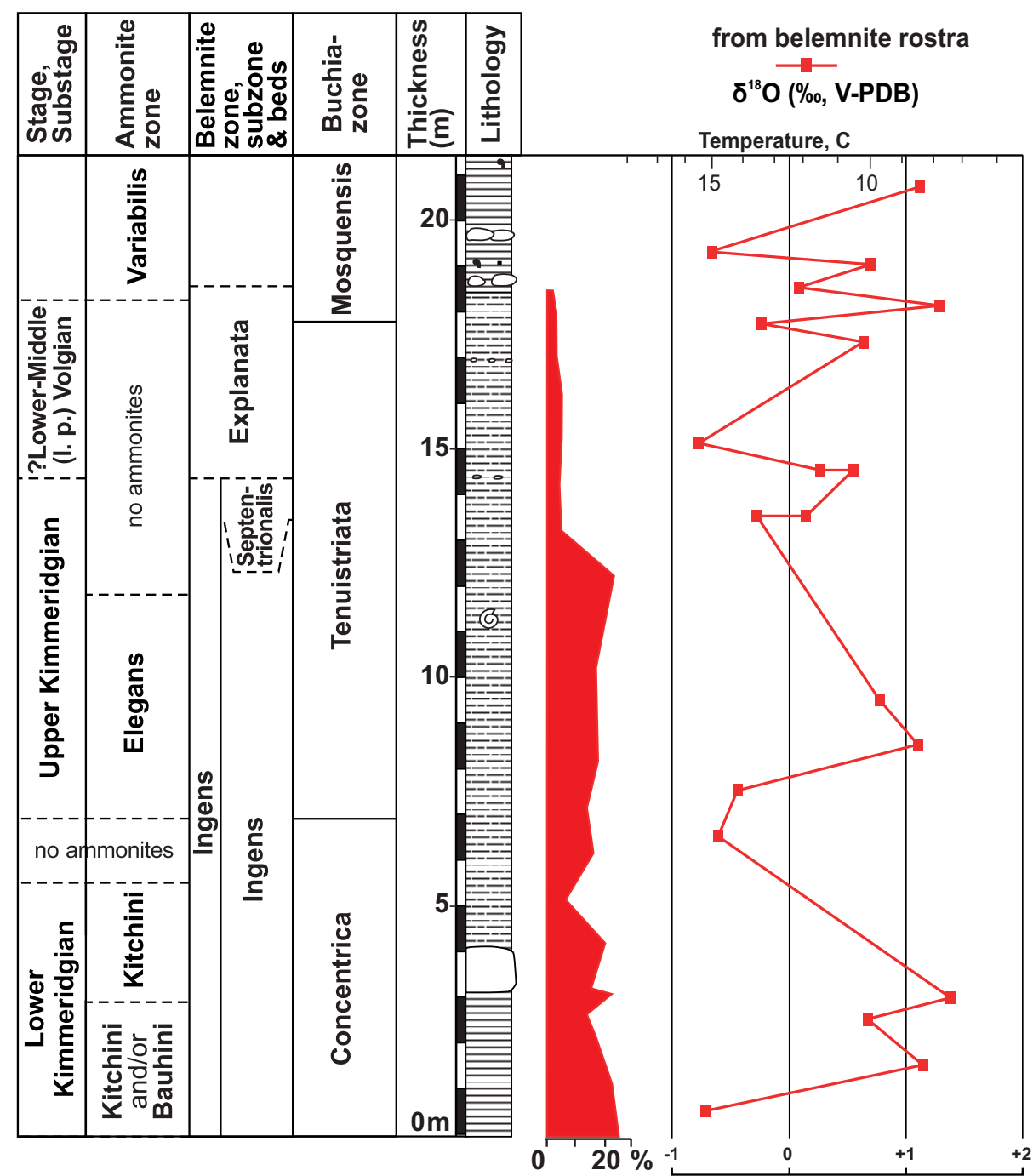

D

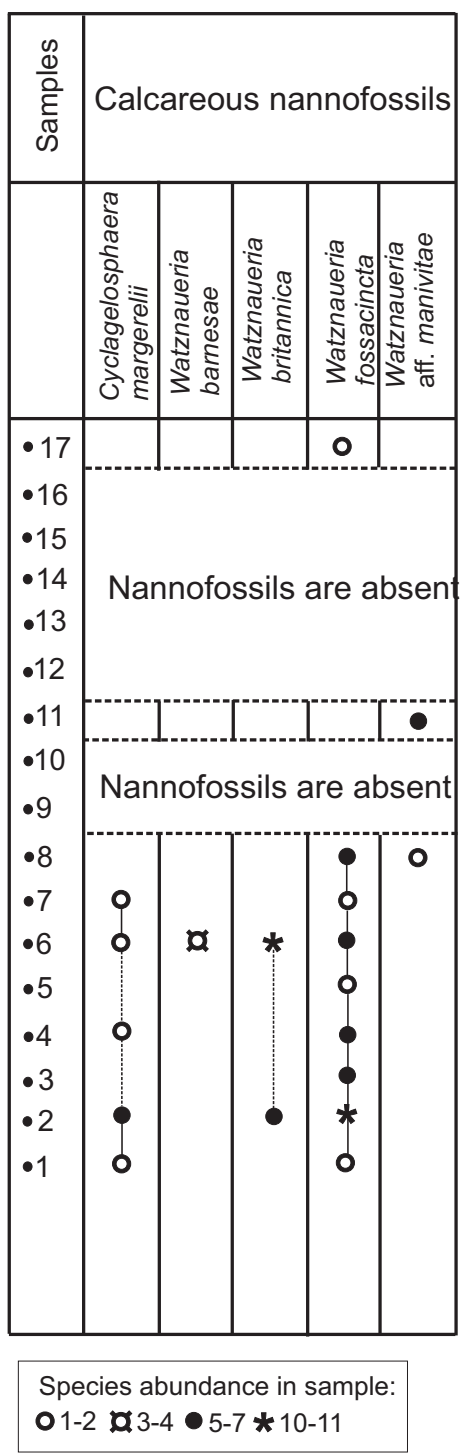

\section{Legend:}

\begin{tabular}{|c|c|c|c|c|c|}
\hline ह" & Claystone & 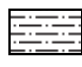 & $\begin{array}{l}\text { Sandy } \\
\text { siltstone }\end{array}$ & $\begin{array}{ll}\cdot & 9 \\
& h\end{array}$ & $\begin{array}{l}\text { Pyrite }(a) \\
\text { glauconite }(b)\end{array}$ \\
\hline 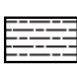 & $\begin{array}{l}\text { Silty } \\
\text { claystone }\end{array}$ & $0^{\circ}$ & $\begin{array}{l}\text { Calcareous } \\
\text { nodules }\end{array}$ & & \\
\hline
\end{tabular}

Figure 2. Kimmeridgian-Middle Volgian succession of the Nordvik section. (A) Lithological log and set of independent zonal scales based on different fossil groups. (B) Relative abundance of thermophilic pollen (based on data from Nikitenko et al., 2015). (C) Oxygen stable-isotope values and their palaeotemperature interpretation (after Zakharov et al., 2014). (D) Samples studied and ranges of nannofossil taxa.

surface. They are represented only by Watznaueriaceae. The nannofossil assemblage includes the following species: Cyclagelosphaera margerelii (Noël), Watznaueria barnesae (Black), Watznaueria britannica (Stradner), Watznaueria fossacincta (Black) and Watznaueria manivitae Bukry (Fig. 3). These cosmopolitan species are known also from the Tithonian of relatively high-latitude sites of the Southern Hemisphere (NW Australian Shelf, DSDP wells 765 and 261, see Bown, 1992).
Corroded surfaces of nannofossils, mainly represented by dissolution-resistant cosmopolitan Watznaueria, indicate diagenetic overprinting of the nannofossil assemblage. W. barnesae is considered as a non-specialised species that easily inhabited new niches, indicative fof lownutrient and warmer surface waters (Ruffell et al., 2002 and references therein). 

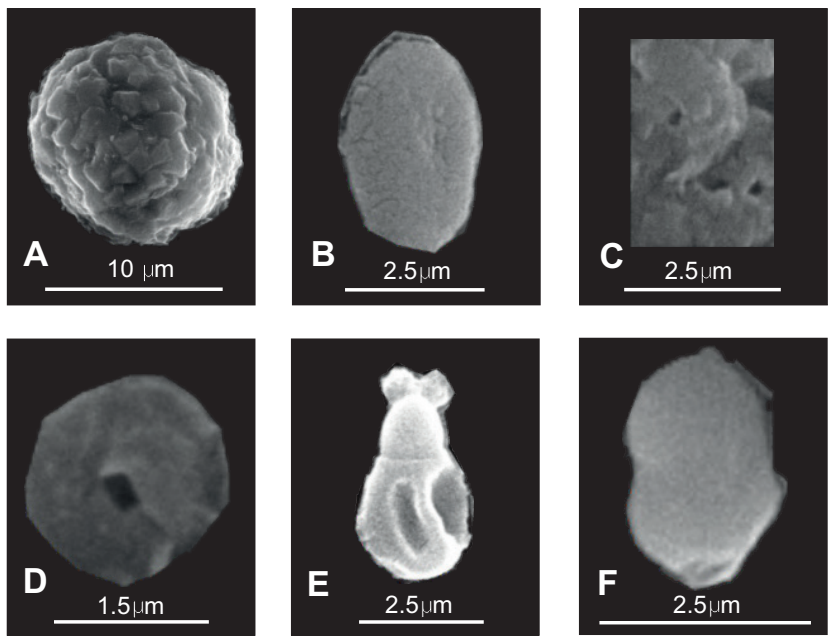

Figure 3. Selected nannofossils from the Kimmeridgian of the Nordvik section. (A) Watznaueria aff. manivitae Bukry, distal view, sample 11. (B) Watznaueria fossacincta (Black), distal view, sample 6. (C) Cyclagelosphaera margerelii Noel, distal view, sample 6. (D) Watznaueria barnesae (Black), distal view, sample 6. (E, F) Unknown species, sample 6.

\section{Discussion}

Despite the absence of Subboreal ammonites in the Kimmeridgian of the Nordvik section, numerous aulacostephanid records are known from the relatively shallow Kimmeridgian deposits of the Khatanga depression and eastern Taimyr, located a few hundred kilometres from the studied section (Fig. 4). Being very common throughout the Kimmeridgian in the Kheta and Boyarka successions, aulacostephanids are rare in northern sections. In the sand-dominated, shallowwater deposits of the eastern Taimyr (AH-3 borehole and Chernokhrebetnaya section), aulacostephanids are known only from the Upper Kimmeridgian, and the succession is strongly dominated by cardioceratids. Aulacostephanids are also recorded southeast of the Nordvik section, from the near-shore sands of the Anabar river. However, shallow-water sands and sandstones of the northern Taimyr (Anzhelika and Pregradnaya, see Fig. 4) lack aulacostephanids. As has been shown by Mesezhnikov (1984), in the Kheta river basin the relative abundance of aulacostephanid ammonites gradually increased during the Early Kimmeridgian and exceeds $70 \%$ at the Mutabilis Chron, although as follows from the authors' observations, these values might be significantly overestimated. Later (Eudoxus Chron), these ammonites became less abundant and finally extinct, as their occurrence is entirely unknown from the latest Kimmeridgian Suboxydiscites taimyrensis Chron (Fig. 5). West Siberian aulacostephanid ammonites resemble those of northern Siberia (Meledina, 2005; Rogov, 2016), and are particularly common at some levels (cf., Rogov, 2016), while in the Subpolar Urals aulacostephanids were the dominant group of ammonites during the whole Kimmeridgian, except in its uppermost subzone (Mesezhnikov, 1984, see also Fig. 5).
Ammonite successions of the Kheta river basin and Subpolar Urals are richer in aulacostephanids than in some relatively low-latitude successions (see Rogov, 2012). Kimmeridgian ammonite assemblages of the Barents Sea shelf, Spitsbergen and Franz-Josef Land are mainly dominated by cardioceratids, while Subboreal aulacostephanids are restricted to thin intervals. These are cymodoce and sachsi horizons (Rogov, 2014; Rogov \& Poulton, 2015), indicating brief occurrences of the Rasenia ex gr. cymodoce (d'Orb.) and Zenostephanus sachsi (Mesezhn.) within the Early Kimmeridgian Cymodoce and early Late Kimmeridgian Mutabilis Chrons, respectively. Such a 'Subboreal' character of the ammonite assemblages of the Subpolar Urals and Khatanga depression, particularly compared with the sparse aulacostephanid succession in the Arctic islands, provides evidence for a strong influence of the Middle Russian Sea on the ammonite assemblages of Western and Northern Siberia (Rogov, 2012), and suggests the existence of warm, eastward-flowing currents from the Middle Russia Sea during the Late Jurassic. Patterns of aulacostephanid distribution in the Yenisei-Khatanga depression strongly support a climatic control on occurrences of these ammonites.

A gradual increase in temperature in the Boreal basins during the Late Jurassic is well recognised in other areas, such as in Scotland (Nunn et al., 2009), Russian Platform (Price \& Rogov, 2009; Wierzbowski et al., 2013), the Subpolar Urals (Zakharov et al., 2005) and more recently in the Nordvik area (Žák 'et al., 2011; Zakharov et al., 2014). This remarkable trend only partially corresponds to contemporaneous changes in ammonite assemblages (Price \& Rogov, 2009; Wierzbowski et al., 2013). This phenomenon could be explained by differences in depth of habitats of the belemnites (near-bottom dwellers) 


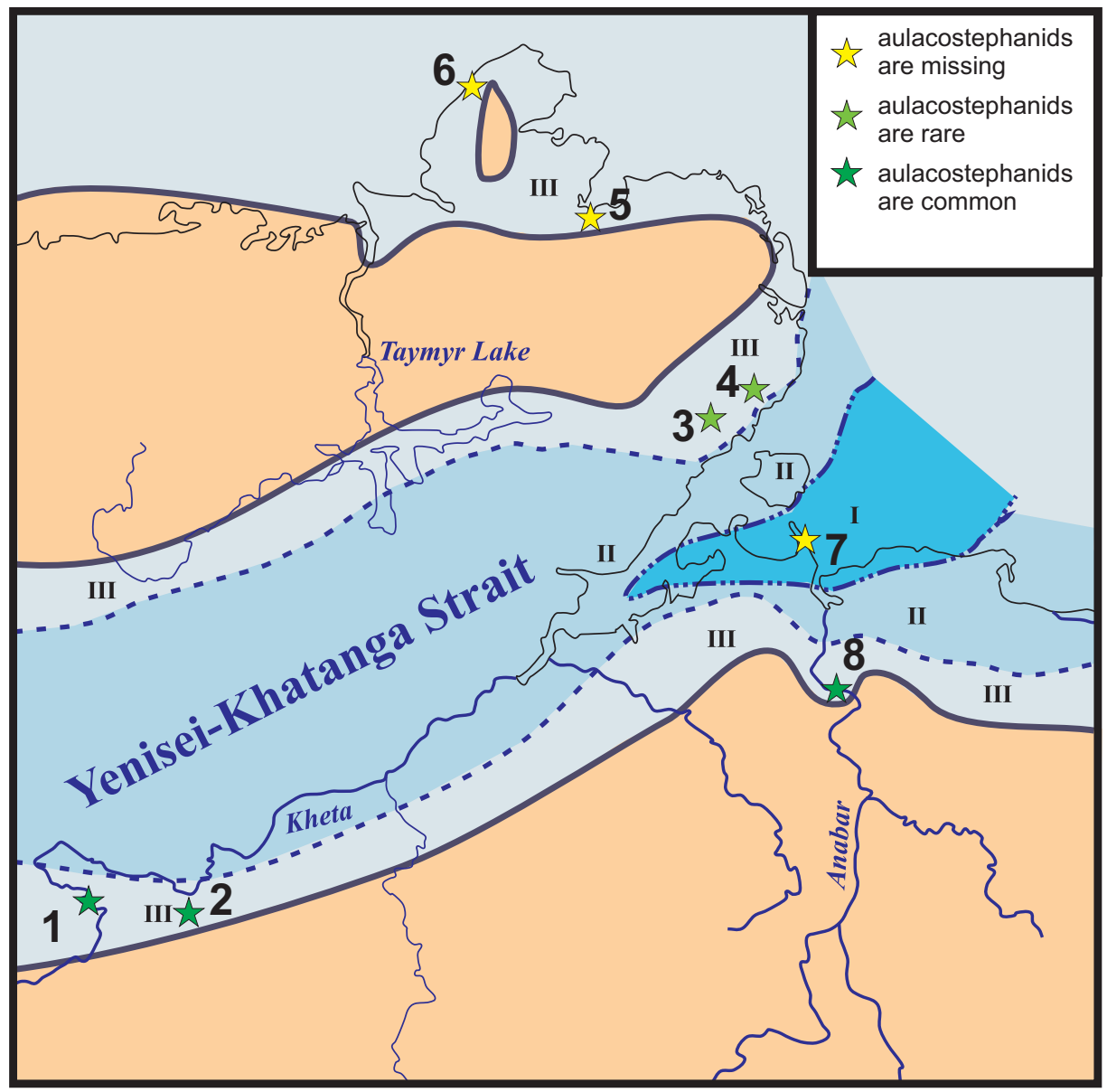

Figure 4. Simplified palaeogeographic map of the Yenisei-Khatanga Strait during the Kimmeridgian with positions of the discussed sections. (1) Kheta. (2) Boyarka. (3) Borehole AH-3. (4) Chernokhrebetnaya. (5) Pregradnaya. (6) Anzhelika. (7) Nordvik. (8) Anabar. Roman numerals mark the positions of different zones in the basin: (I) Deep-water black shales with local siltstones. (II) Relatively deep, sublittoral deposits, consisting mainly of silt and siltstones. (III) Shallow-water, sand-dominated facies.

\begin{tabular}{|c|c|c|}
\hline \multirow{2}{*}{ 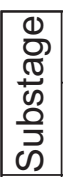 } & \multicolumn{2}{|c|}{ Zone } \\
\hline & Subboreal & Boreal \\
\hline \multirow{4}{*}{ 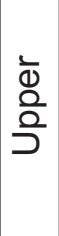 } & Autissiodor. & Taimyrens \\
\hline & Eudoxus & Decipiens \\
\hline & & Sokolovi \\
\hline & Mutabilis & \multirow{2}{*}{ Kitchini } \\
\hline \multirow{2}{*}{ ఏై } & Cymodoce & \\
\hline & Baylei & Bauhini \\
\hline
\end{tabular}

\section{Subpolar Urals}

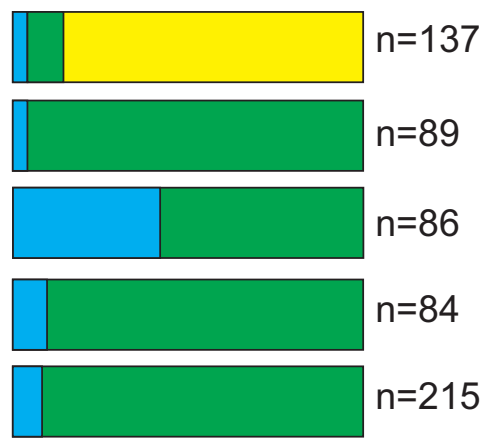

\section{Khatanga depression (Boyarka)}

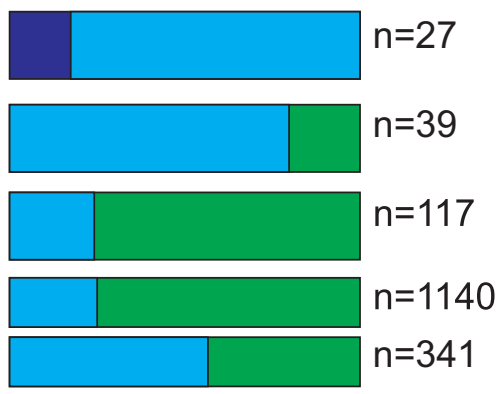

\section{Legend:}

$\square \begin{aligned} & \text { Boreal } \\ & \text { Oppeliidae } \square \text { Aulacostephanidae }\end{aligned}$
$\square$ Cardioceratidae $\square$ Virgatitidae

Figure 5. Kimmeridgian ammonite assemblages of the Subpolar Urals and the Khatanga depression (after Mesezhnikov, 1984). 
and ammonites (near-surface animals), as well as by palaeogeographical factors influencing ammonoid distribution, and/or by the influence of salinity on the oxygen stable-isotope values, which may obscure the effects of palaeotemperature. Independent evidence for Late Jurassic high-latitude warming could be found through analysis of palynological data. Recently, Classopolis and other thermophilic pollen were found in Oxfordian and Kimmeridgian samples from the Nordvik section (Nikitenko et al., 2015, see also Fig. 2).

The presence of nannofossils in the Nordvik section could be explained by the influence of surface currents from the warmer and shallower Khatanga Strait and/ or by their occasional occurrences during brief climate oscillations. A Late Jurassic northeastward-flowing current through the Khatanga Strait seems likely, as the nannofossils' presence corresponds well to molluscan distributional patterns. For the latest Jurassic (Late Volgian) to Early Cretaceous, the presence of such a current was suggested by Baraboshkin et al. (2007). Such a pattern of currents also corresponds well with Kimmeridgian-Tithonian reconstructions presented by Moore et al. (1992).

\section{Conclusions}

For the first time, calcareous nannoplankton of Late Jurassic age have been identified in polar latitudes $\left(\sim 78^{\circ} \mathrm{N}\right)$. Although poor in diversity and of moderate preservation, this finding is very important as it sheds light on Late Jurassic palaeoclimate and palaeogeography. Along with other lines of evidence, the presence of Kimmeridgian nannoplankton in Northern Siberia suggests a relatively warm climate in this region, which is supported by a number of other proxies (e.g., the presence of numerous sub-boreal ammonites in the nearby sea strait, oxygen stable-isotope values and the presence of thermophilic pollen).

Acknowledgements. This study has been supported by the Russian Science Foundation grant no. 17-17-01171. Jorg Mutterlose (Bochum) made some useful comments on an early draft of this manuscript. Morten Smelror is thanked for his valuable comments and suggestions that led to improvements in the paper.

\section{References}

Baraboshkin, E.J., Naidin, D.P., Beniamovski, V.N., Herman, A.B. \& Ahmetiev ,M.A. 2007: Straits of the Northern Hemisphere in the Cretaceous and Paleogene. Moscow State University publishing house, Moscow, $182 \mathrm{pp}$. [in Russian]

Bown, P.R. 1992: New Calcareous Nannofossil Taxa from the Jurassic/ Cretaceous Boundary Interval of Sites 765 and 261, Argo Abyssal Plain. Proceedings of the Ocean Drilling Program, Scientific Results 123, 369-379.

Bown, P.R. 1996: Recent advances in Jurassic calcareous nannofossil research. In Riccardi A. (ed.): Advances in Jurassic Research. GeoResearch Forum 1-2, pp. 55-60.

Bragin, V.Y., Dzyuba, O.S., Kazansky, A.Y. \& Shurygin, B.N. 2013: New data on the magnetostratigraphy of the Jurassic-Cretaceous boundary interval, Nordvik Peninsula (northern East Siberia). Russian Geology and Geophysics 54, 335-348. https://doi.org/10.1016/j.rgg.2013.02.008.

Dzyuba, O.S. 2012: Belemnites and biostratigraphy of the JurassicCretaceous boundary deposits of northern East Siberia: new data on the Nordvik Peninsula. Stratigraphy and Geological Correlation 20, 53-72. https://doi.org/10.1134/S0869593811060037.

Dzyuba, O.S., Izokh, O.P. \& Shurygin, B.N. 2013: Carbon isotope excursions in Boreal Jurassic-Cretaceous boundary sections and their correlation potential. Palaeogeography, Palaeoclimatology, Palaeoecology 381, 33-46. https://doi.org/10.1016/j.palaeo.2013.04.013.

Gavrilov, Y.O., Shchepetova, E.V., Rogov, M.A. \& Shcherbinina, E.A. 2008: Sedimentology, geochemistry, and biota of Volgian carbonaceous sequences in the northern part of the Central Russian Sea (Kostroma Region). Lithology and Mineral Resources 43, 354-379. https://doi.org/10.1134/S002449020804007X.

Houša, V., Pruner, P., Zakharov, V.A., Kostak, M., Chadima, M., Rogov, M.A., Šlechta, S. \& Mazuch, M. 2007: Boreal-Tethyan correlation of the Jurassic-Cretaceous boundary interval by magneto- and biostratigraphy. Stratigraphy and Geological Correlation 15, $297-$ 309. https://doi.org/10.1134/S0869593807030057.

Meledina, S.V. 2005: Ammonite biostratigraphy and biogeographic classification of the West Siberian basin in the Kimmeridgian. Russian geology and geophysics 46, 989-1002.

Mesezhnikov, M.S. 1984: Kimmeridgian and Volgian Stages of north of the USSR. Nedra, Leningrad, 224 pp. [in Russian]

Moore, G.T., Sloan, L.C., Hayashida, D.N. \& Umrigar N.P. 1992: Paleoclimate of the Kimmeridgian/Tithonian (Late Jurassic) world: II. Sensitivity tests comparing three different paleotopographic settings. Palaeogeography, Palaeoclimatology, Palaeoecology 95, 229252. https://doi.org/10.1016/0031-0182(92)90143-S.

Mutterlose, J. \& Kessels, K. 2000: Early Cretaceous calcareous nannofossils from high latitudes: implications for palaeobiogeography and palaeoclimate. Palaeogeography, Palaeoclimatology, Palaeoecology 160, 347-372. https://doi.org/10.1007/BF03021757.

Mutterlose, J., Brumsack, H., Flögel, S., Hay, W., Klein, C., Langrock, U., Lipinski, M., Ricken, W., Söding, E., Stein, R. \& Swientek, O. 2003: The Greenland-Norwegian Seaway: a key area for understanding Late Jurassic to Early Cretaceous paleoenvironments. Paleoceanography 18. https://doi.org/10.1029/2001PA000625.

Mutterlose, J., Bornemann, A. \& Herrle, J.O. 2005: Mesozoic calcareous nannofossils - state of the art. Paläontologische Zeitschrift 79, 113133. https://doi.org/10.1007/BF03021757.

Nikitenko, B.L., Pestchevitskaya, E., Lebedeva, N. \& Ilyina, V. 2008: Micropalaeontological and palynological analyses across the Jurassic-Cretaceous boundary on Nordvik Peninsula, Northeast Siberia. Newsletters on stratigraphy 42, 181-222. https://doi.org/10.1127/0078-0421/2008/0042-0181.

Nikitenko, B.L., Shurygin, B.N., Knyazev, V.G., Meledina, S.V., Dzyuba, O.S., Lebedeva, N.K., Peshchevitskaya, E.B., Glinskikh, L.A., Goryacheva, A.A. \& Khafaeva, S.N. 2013: Jurassic and Cretaceous 
stratigraphy of the Anabar area (Arctic Siberia, Laptev Sea coast) and the Boreal zonal standard. Russian Geology and Geophysics 54, 808-837. https://doi.org/10.1016/j.rgg.2013.07.005.

Nikitenko, B.L., Knyazev, V.G., Peshchevitskaya, E.B. \& Glinskikh, L.A. 2015: The Upper Jurassic of the Laptev Sea: interregional correlations and paleoenvironments. Russian Geology and Geophysics 56, 1173-1193.

https://doi.org/10.1016/j.rgg.2015.07.008.

Nunn, E.V., Price, G.D., Hart, M.B., Page, K.N. \& Leng, M.J. 2009: Isotopic signals from Callovian-Kimmeridgian (Middle-Upper Jurassic) belemnites and bulk organic carbon, Staffin Bay, Isle of Skye, Scotland. Journal of the Geological Society 166, 633-664. https://doi.org/10.1144/0016-76492008-067.

Price, G.D. \& Rogov, M.A. 2009: An isotopic appraisal of the Late Jurassic greenhouse phase in the Russian Platform. Palaeogeography, Palaeoclimatology, Palaeoecology 273, 41-49. https://doi.org/10.1016/j.palaeo.2008.11.011.

Rogov, M.A. 2012: Latitudinal gradient of taxonomic richness of ammonites in the Kimmeridgian-Volgian in the Northern Hemisphere. Paleontological Journal 46, 148-156. https://doi.org/10.1134/S0031030112020104.

Rogov, M.A. 2014: An infrazonal ammonite biostratigraphy for the Kimmeridgian of Spitsbergen. Norwegian Petroleum Directorate Bulletin 11, 153-165.

Rogov, M.A. 2016: New zonal and infrazonal scales for the Kimmeridgian in Western Siberia based on cardioceratid ammonites. Stratigraphy and Geological Correlation 24, 503-526. https://doi.org/10.1134/S0869593816050051.

Rogov, M. \& Wierzbowski, A. 2009: The succession of ammonites of the genus Amoeboceras in the Upper Oxfordian-Kimmeridgian of the Nordvik section in northern Siberia. Volumina Jurassica 7, 147-156.

Rogov, M.A. \& Poulton, T.P. 2015: Aulacostephanid ammonites from the Kimmeridgian (Upper Jurassic) of British Columbia (western Canada) and their significance for correlation and palaeobiogeography. Bulletin of Geosciences 90, 7-20. https://doi.org/10.3140/bull.geosci.1501.

Ruffell, A.H., Price, G.D., Mutterlose, J., Kessels, K., Baraboshkin, E. \& Gröcke, D.R. 2002: Palaeoclimate indicators (clay minerals, calcareous nannofossils, stable isotopes) compared from two sections in the late Jurassic of the Volga Basin (SE Russia). Geological Journal 37, 17-33. https://doi.org/10.1002/gj.903.

Schnabl, P., Pruner, P. \& Wimbledon, W.A. 2015: A review of magnetostratigraphic results from the Tithonian-Berriasian of Nordvik (Siberia) and possible biostratigraphic constraints. Geologica Carpathica 66, 489-498.

https://doi.org/10.1515/geoca-2015-0040.

Smelror, M., Mørk, A., Monteil, E., Rutledge, D. \& Leereveld, H. 1998: The Klippfisk Formation - a new lithostratigraphic unit of Lower Cretaceous platform carbonates on the Western Barents Shelf. Polar Research 17, 181-202.

https://doi.org/10.1111/j.1751-8369.1998.tb00271.x.

Ustinova, M.A. 2009: The distribution of calcareous nannofossils and foraminifers in the Callovian, Oxfordian, and Volgian deposits in the southwest of Moscow. Stratigraphy and Geological Correlation 17, 204-217. https://doi.org/10.1134/S0869593809020087.

Ustinova, M.A. 2017a: Micropalaeontological characteristics (foraminifera and calcareous nannoplanton) of the Lower Kimmeridgian of Bolgary section (Vladimir region). Transaction of the Geological Institute 615, 311-319. [in Russian]

Ustinova, M.A. 2017b: New data on the distribution of calcareous nannofossils in the Upper Jurassic Loino section (Kirov region, Russia). Paleontological Journal 51, 95-106. https://doi.org/10.1134/S0031030117010129.

van Hinsbergen, D.J., de Groot, L.V., van Schaik, S.J., Spakman, W., Bijl, P.K., Sluijs, A., Langereis, C.G. \& Brinkhuis, H. 2015: A paleolatitude calculator for paleoclimate studies. PloS one 10(6).

https://doi.org/10.1371/journal.pone.0126946.
Wierzbowski, A. \& Smelror, M. 1993: Ammonite succession in the Kimmeridgian of southwest Barents Sea, and the Amoeboceras zonation of the Boreal Kimmeridgian. Acta geologica Polonica 43, 229-249.

Wierzbowski, A. \& Rogov, M.A. 2013: Biostratigraphy and ammonites of the Middle Oxfordian to lowermost Upper Kimmeridgian in northern Central Siberia. Russian Geology and Geophysics 54, 1083-1102. https://doi.org/10.1016/j.rgg.2013.07.021.

Wierzbowski, H., Rogov, M.A., Matyja, B.A., Kiselev, D. \& Ippolitov, A. 2013: Middle-Upper Jurassic (Upper Callovian-Lower Kimmeridgian) stable isotope and elemental records of the Russian Platform: indices of oceanographic and climatic changes. Global and Planetary Change 107, 196-212. https://doi.org/10.1016/j.gloplacha.2013.05.011.

Zakharov, V.A. \& Rogov, M.A. 2008: The Upper Volgian Substage in Northeast Siberia (Nordvik Peninsula) and its Panboreal correlation based on ammonites. Stratigraphy and Geological Correlation 16, 423-436. https://doi.org/10.1134/S0869593808040059.

Zakharov, V.A., Nalnyaeva, T.I. \& Shulgina, N.I. 1983: New data on the biostratigraphy of the Upper Jurassic and Lower Cretaceous deposits on Paksa peninsula, Anabar embayment (north of the Middle Siberia). Transactions of the Institute of geology and geophysics, Siberian Branch of the Academy of Sciences of the USSR 528, 56-99. [in Russian)]

Zakharov, V.A., Baudin, F., Dzyuba, O.S., Daux, V., Zverev, K.V. \& Renard, M. 2005: Isotopic and faunal record of high paleotemperatures in the Kimmeridgian of Subpolar Urals. Russian Geology and Geophysics 46, 3-20.

Zakharov, V.A., Rogov, M.A., Dzyuba, O.S., Žák, K., Košt’ák, M., Pruner, P., Skupien, P., Chadima, M., Mazuch, M. \& Nikitenko, B.L. 2014: Palaeoenvironments and palaeoceanography changes across the Jurassic/Cretaceous boundary in the Arctic realm: case study of the Nordvik section (north Siberia, Russia). Polar research 33. https://doi.org/10.3402/polar.v33.19714.

Zanin, Y.N., Zamirailova, A.G. \& Eder, V.G. 2012: Some Calcareous Nannofossils from the Upper Jurassic-Lower Cretaceous Bazhenov Formation of the West Siberian Marine Basin, Russia. The Open Geology Journal 6, 25-31. https://doi.org/10.2174/1874262901206010025.

Žák, K., Košták, M., Man, O., Zakharov, V.A., Rogov, M.A., Pruner, P., Rohovec, J., Dzyuba, O.S. \& Mazuch, M. 2011: Comparison of carbonate $\mathrm{C}$ and $\mathrm{O}$ stable isotope records across the Jurassic/ Cretaceous boundary in the Tethyan and Boreal Realms. Palaeogeography, Palaeoclimatology, Palaeoecology 299, 83-96. https://doi.org/10.1016/j.palaeo.2010.10.038. 